\title{
Business Angel-Venture Negotiation in the Post-Investment Relationship: The Use of the Good Cop, Bad Cop Strategy
}

\author{
Andreas Fili \\ Centre for Banking and Finance, KTH Royal Institute of Technology, Sweden \\ Drottning Kristinas väg 30, S-100 44, Sweden
}

Phone: 0046737465784

Fax: 004684117436

E-mail: andreas.fili@abe.kth.se

The paper reports on the utilization of the 'good cop, bad cop' negotiation strategy in ongoing investor-venture relationships. Four cases of business angel - venture involvement are studied over several years' time. Earlier research on the good cop, bad cop strategy has described its efficiency in obtaining maximum distribution in short-term distributive bargaining. This has been explained as a result of the emotional contrast effect unlocked by the sequence of interaction with the bad cop followed by interaction with the good cop. In an ongoing investment relationship, other rules apply. The present findings suggest that only a business angel who is already trusted can become a good cop - by virtue of introducing a bad cop. This is explained as a way of conducting negotiations without destroying the trust that has been built over time in the business angel - venture relationship. The strategy provides a scapegoat for the negativity associated with the negotiations. The bad cop assumes the blame, while the good cop is still trusted and can remain in the relationship, with less risk of being the target of any retained hostility.

Keywords: Business angel, 'good cop, bad cop', negotiation, reciprocal exchange, attribution 


\section{Introduction}

One of the essential concerns for an investor is to ascertain that the invested resources are being put to proper use in the venture in accordance with the terms of the investment contract (Jensen and Meckling 1976). Traditional solutions have been to design incentive schemes or engage in monitoring, but research suggests that there are drawbacks to both these methods (Tosi, Katz and Gomez-Meija 1997; Deci, Koestner and Ryan 1999; Falk and Kosfeld 2006). Instead, it has been argued that trust can substitute for control as a means of organizing interorganizational relationships (Ring and Van de Ven 1994; Costa and Bijlsma-Frankema 2007).

However, this coordination needs to accommodate change. Ventures face high uncertainty and need to make continuous changes along the way, such as changing the market offering, targeting other markets and segments, adopting alternative growth strategies, or acquiring finance in other ways than initially planned. Such changes may cause task conflicts where both investors and ventures feel that the terms of agreement should be renegotiated to reflect the new situation. Such negotiation can be hard as both parties can stand to lose a lot, but still they want to avoid escalation into a relationship conflict (Jehn 1995). Even though it has been suggested that conflict is an unavoidable part of the investor-venture relationship (Yitshaki 2008), relationship conflicts are entirely negative for performance (De Dreu and Weingart 2003). Therefore, once negotiations are necessary, an important question for investors would be how to avoid relationship conflict and preserve the trust that they have managed to build, by choosing negotiation strategies carefully.

In the negotiation literature, an emotional contrast negotiation strategy called good cop, bad cop has been described (Rafaeli and Sutton 1991; Hilty and Carnevale 1993; Brodt and Tuchinsky 2000), although not within ongoing relationships. The purpose of the present study is to conduct an in-depth analysis of how and when the good cop, bad cop strategy is used in investor-venture relationships, by studying four cases where Swedish business angels have negotiated with their ventures.

\section{Business angels and the risks of venture investments}

A business angel is defined as "a high net worth individual, acting alone or in a formal or informal syndicate, who invests his or her own money directly in an 
unquoted business in which there is no family connection and who, after making the investment, generally takes an active involvement in the business, for example, as an advisor or member of the board of directors" (Mason and Harrison 2008, p. 309). Traditional business angels invest alone, but it seems that even such lone angels to a large extent actually coordinate their investments informally with a few trusted business angels, not to mention those who choose to participate in larger, formal angel networks or even angel funds (Shane 2008).

Business angels are limited by the size of their own wealth in their ability to diversify. Therefore, they focus on avoiding bad investments rather than finding the best ones, because they will have difficulty exiting the venture if it is performing poorly (Mason and Harrison 2002). Thus, business angels are committed to their ventures through non-recoverable investments (Parkhe 1993a).

Through active involvement in their ventures, business angels create value in several ways (for a review, see Politis 2008). It has been argued that the postinvestment relationship is characterized by a high degree of informality and a strong social element, and that the involvement of business angels is better understood as a personal relationship (Paul, Whittam and Wyper 2007). The business angel acts as a mentor (Brettel 2003; Amatucci and Sohl 2004; Madill, Haines and Riding 2005, Macht 2011) or as a member of the entrepreneurial team (Sörheim 2005). The majority of business angels once started as entrepreneurs and still perceive themselves as co-entrepreneurs rather than investors (Politis and Landström 2002), exhibiting a strong entrepreneurial orientation (Lindsay 2004). Still, at times during the relationship, there will be goal divergence between investor and venture (Sapienza and Gupta 1994).

Task conflicts have been defined as conflicts that arise because of different views on how to define and solve a certain task, while relationship conflicts are personal in nature (Jehn 1995). While both are detrimental for performance (De Dreu and Weingart 2003), relationship conflict has an even stronger negative effect, although this has not been confirmed in investor-venture relationships (Collewaert 2012). It has been suggested that task conflict may escalate into relationship conflict (Pondy 1967). Thus, when a task conflict arises in the post-investment relationship, the business angel would want to negotiate in such a way that relationship conflict is avoided. 
The post-investment venture involvement has been studied through three major theoretical perspectives; agency theory (Van Osnabrugge 2000; Arthurs and Busenitz 2003), stewardship theory (Davis, Schoorman and Donaldson 1997), and procedural justice, as evidenced in the timing of communication and feedback (Sapienza and Korsgaard 1996). Agency theory has focused mainly on how to ensure compliance through monitoring and control (Ross 1973), whereas stewardship theory maintains that compliance can be achieved through reliance on trust. There has been considerable research devoted to the link between trust and governance in relationships; specifically whether they act as substitutes or complements (see Puranam and Vanneste 2009 for a review of the literature).

What sets negotiation during the post-investment setting apart is the fact that the business angel may have become a trusted venture insider and/or mentor, and thus inhabits a role more in line with stewardship, but suddenly needs to negotiate in the role of investor. Thus, there is a need to switch between a trusting personal relationship and a bargaining situation. Such switches have been studied within social exchange theory.

\section{Reciprocal and negotiated exchange}

In research on social exchange, a distinction is made between negotiated and reciprocal exchange, each with its own specific rules and effects on the actors (Molm 2000). Negotiated exchange is defined as bilateral transactions, exemplified through explicit bargaining over benefits. These transactions are discrete in time. Its opposite is reciprocal exchange. It evolves gradually, and discrete transactions are not easily identified. Instead, each actor performs a beneficial act for the other without knowing if the other will give something back. (Molm 2003, p. 3) It is the particular form of exchange that decides its impact. Trust develops as a result of the reciprocal form of social exchange, because the psychological state of trust can arise only when there is sufficient time to be vulnerable, in the time between reciprocal acts. Conversely, because of its competitive nature, a negotiated exchange will be perceived as less fair by each actor than a structurally equivalent reciprocal exchange with an equivalent outcome (Molm, Peterson and Takahashi 2003).

Translating this to the business angel-venture setting, it has been shown that business angels seldom invest in ventures that they do not already trust to a certain 
extent (Mason and Harrison 2002; Sudek 2006). Thus, there is - at least - a certain hygiene level of trust. Apart from this, initially there would be negotiated exchange, preinvestment, in a joint decision process where the terms of the contract are being negotiated and settled. There is negotiation between the investor and the venture, and through explicit bargaining over equity, influence, and funding, an agreement is struck where each actor wins only at the other's expense; in a zero-sum game.

This state of negotiation is not permanent. The initial state of primarily negotiated exchange gives way to reciprocal exchange, during the post-investment relationship, where acts are reciprocated over longer time periods, enabling the creation of trust. During the trusting post-investment relationship, discrete transactions are hard to identify. However, reciprocal exchange may be changed back into negotiated exchange, for example if there is a need for additional financing. Social exchange theory states that switching to bargaining from a trustful relationship means switching to negotiated exchange from reciprocal exchange, which implies that there will be a negative impact on the post-investment relationship in terms of trust and commitment. Indeed, investors harbor expectations of goal divergence and opportunistic behavior from entrepreneurs during investment rounds (Christensen, Wuebker and Wüstenhagen 2009).

Therefore, theory suggests that once engaged in a reciprocal exchange with the venture, the business angel would prefer not to re-engage in negotiated exchange, and risk a loss of trust. However, as will be evident in the following four cases, in certain situations, the goals diverge between the venture and the business angel, leading to a need for negotiations.

\section{The negotiation process}

Spector (1977) proposes a three-phase model for negotiation. In the model, two adversaries bargain. This model is divided in three phases: the background phase, the process phase, and the outcome phase. In the background phase, personality and perceptions/expectations are included as psychological factors that affect both the bargaining phase and the outcome phase. Thus, bargaining behavior is a function of both the background factors as well as a response to the behavior of the adversary. 


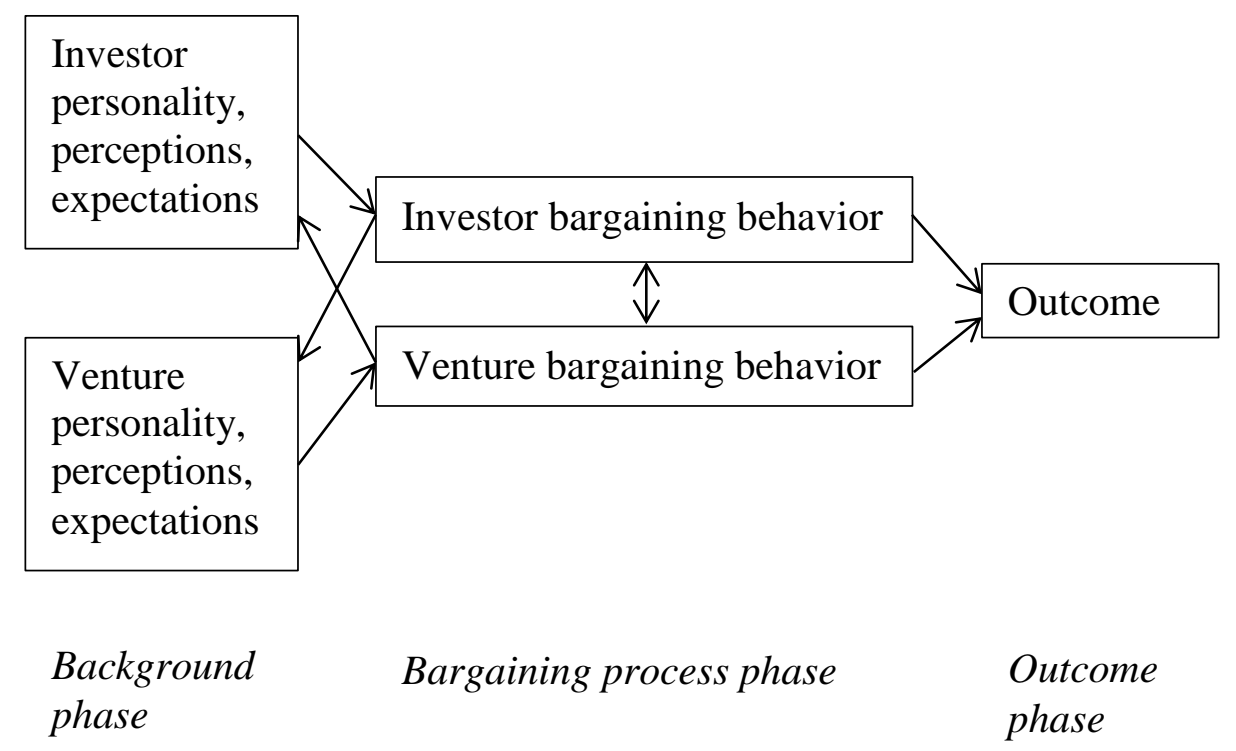

Figure 1. The negotiation process (adapted from Spector 1977).

In the top half of the figure, the investor has been placed. In the bottom half of the figure, the venture is placed. A more precise description of our four cases is that the adversary is the venture CEO, who is either the venture founder or someone recruited at a later time.

Although deceptively simple, this model suggests that the behavior of each business angel during negotiations is limited by the expectations and perceptions from the venture. Based on previous interaction, the business angel will have built a certain role towards the venture, and the behavior during negotiation needs to stay true to that role. In the current study, the personalities of the business angels and the venture members have not been studied, and although some empirical material comes from the ventures, the major part comes from the business angels. Therefore, the personality factors in the model are not used. Furthermore, the outcome phase is merely touched upon. The outcome is mentioned but not developed, as the focus of the present paper is on the negotiation process.

The intentions of the business angels are central to an understanding of the negotiation process from an interactional justice perspective (Bies and Shapiro 1987), because action is interpreted as much more fair if it is believed that the underlying intentions are benevolent (cf. Collewaert and Fassin 2011). 


\section{The good cop, bad cop negotiating team tactic}

Studies have shown that subjecting people to both positive and negative emotions can produce greater compliance than the display of just one of these emotions, through the emotional contrast effect from their juxtaposition. Relative to each other, positivity is perceived as even more positive, and negativity is perceived as even more negative (Rafaeli and Sutton 1991). In the interrogation of suspects, this technique is known as the good cop, bad cop strategy. One interrogator plays the role of the good cop, supporting and comforting the suspect, whereas the other interrogator plays the role of the bad cop, conveying negative and hostile emotions to the suspect. Team negotiations offer the possibility of each negotiator adopting a highly choreographed role (Brodt and Thompson 2001).

By studying Israeli criminal interrogators and American bill collectors, Rafaeli and Sutton (1991) identify five different variations of the good cop, bad cop strategies. These variations are:

1) Two people play good cop and bad cop in sequence, interacting separately with the target, after each other.

2) Two people play good cop and bad cop simultaneously, both interacting with the target together in the same room.

3) A single individual plays both roles by switching behavior between roles.

4) A single individual plays good cop, and makes reference to a hypothetical bad cop, who is attributed with bad cop behavior.

5) A single individual plays good cop in contrast to a stereotype expectation of a bad cop: the good cop acts only as a good cop, but the expectations of the target is that this individual should exhibit bad cop behavior.

The first variation in the scheme by Rafaeli and Sutton (1991) has been studied in experiments by Hilty and Carnevale (1993) and Brodt and Tuchinsky (2000). Hilty and Carnevale (1993) report on an experiment on bilateral negotiation. They find that the sequence of bad cop followed by good cop, moving from competition towards cooperation, was most likely to achieve agreements. The same findings are reported by Brodt and Tuchinsky (2000). Studying sequences of good cop, bad cop negotiation in an experimental setting of simulated three-person workgroups, they show that the 
traditional sequence, where the bad cop is first introduced, followed by the good cop, is the most effective in obtaining the desired contrast effect, and this effect is critical to the success of the tactic. Both roles were necessary (bad-good); two similar cops (good-good or bad-bad) did not achieve the same effect. They conclude that the good cop, bad cop strategy is very powerful and can be generalized to other settings than that of interrogation. However, they provide some evidence that participants are less willing to work with a bad cop again, and pose the question how people would use the good cop, bad cop strategy in ongoing relationships.

\section{Method}

Four cases were selected, for the following reasons. First, by limiting the cases to four, each case could be described in detail in the empirical section of the paper. Four cases can be sufficient in exploratory case research with the aim of creating new theory (Eisenhardt 1989). Second, the data I was able to access in these particular four cases was richer and more varied. Cases based on only a single method of data collection, such as interviews, are exposed to a potential common-method bias (Podsakoff et al. 2003). In order to decrease the risk of this bias, triangulation was performed by supplementing the interviews with other data sources and methods (cf. Yin 1994), such as repeated informal observations, speaking to the venture founders, as well as checking the annual reports of the ventures as many years back as possible. Thus, these four cases each provided an opportunity for learning in terms of access and different data sources, key criteria for case selection (Stake 2005). Third, the cases each had the potential of extending current theory through slight variation among them, and one of the cases was chosen as a contrasting case (Miles and Huberman 1994). 
Table 1. Case data.

\begin{tabular}{|c|c|c|c|c|}
\hline & Case 1 & Case 2 & Case 3 & Case 4 \\
\hline $\begin{array}{l}\text { Interviews } \\
\text { with business } \\
\text { angel }\end{array}$ & 3 & 3 & 2 & 2 \\
\hline Observations & No & No & Yes & Yes \\
\hline $\begin{array}{l}\text { Interview } \\
\text { with venture }\end{array}$ & No & No & Yes & Yes \\
\hline $\begin{array}{l}\text { Annual } \\
\text { reports }\end{array}$ & Yes & No & Yes & Yes \\
\hline
\end{tabular}

In generation of new theory through case analysis, an overlap between data collection and data analysis is fruitful (Eisenhardt 1989). In the present study, data collection through the interviews took place over a four-year period, involving iteration between the cases and collection/analysis (cf. Parkhe 1993b). A total of 30 face-to-face, semistructured interviews with 21 business angels, were performed from 2008 to 2012, on the topic of governance strategies in both times of harmony and conflict. The good cop, bad cop strategy was unearthed during early interviews in the research project. Analysis of the data was undertaken in three periods, during which there was iteration between analysis and collection of new data. The first period was during the first 6 months of data collection, when the strategy was first identified and tentatively likened to the good cop, bad cop strategy from movies. After this, other potential instances of this particular strategy were identified among the interviews, and three more cases were selected.

The initial interviews were all taped and transcribed verbatim, and ranged between 1.5 and 2 hours per interview. During the second period, follow-up interviews were conducted in order to deepen the understanding gained from the initial accounts (Polkinghorne 2005), theory was searched, and the second wave of data analysis ensued. Because there was little evidence of this particular negotiation strategy in the existing literature on post-investment relationships, follow-up interviews asked respondents to focus on a particular recent episode of negotiations, in a total of six follow-up interviews, typically around one hour long. The follow-up interview material was partly transcribed, and therefore all the parts that were used in the final paper that had not been transcribed were presented to the business angels for 
"member checks" (Shah and Corley 2006) of the details. The iteration between data collection, immersion in theory, and data analysis, and back again to more data collection, allowed for a partly emergent design of the study (Glaser and Strauss 1967; Bruce 2007).

There are some limitations to the present study. It is based on a relatively limited number of cases, and the business angels are Swedish, although active in an international context. The cases were field studies, limiting the control available to the researcher. There has been no inclusion of cases for comparison of the actual effect of the strategy. Instead, the focus has been on describing the phenomenon, and not its impact.

The imminent empirical section begins with a description of the context before negotiations began: in each case, the business angels and the ventures are described, as well as the relationship between them. After context, in line with the phase model by Spector (1977) presented earlier, the empirical material is structured in three major sections: background, process and outcome.

\section{The context before negotiations}

This section of the paper starts with a description of the business angels in terms of their experience as entrepreneurs, before becoming business angels, under the assumption that their unique individual entrepreneurial experience of learning through problem solving has shaped their basic assumptions and the way they perceive ventures (cf. Schein 2006).

Table 2. The experience of the business angels (BA).

\begin{tabular}{|c|c|c|c|c|}
\hline & BA 1 & BA 2 & BA 3 & BA 4 \\
\hline Age & $30-40$ & $30-40$ & $50-60$ & $50-60$ \\
\hline $\begin{array}{l}\text { Entrepreneurial } \\
\text { background } \\
\text { before } \\
\text { becoming a BA }\end{array}$ & $\begin{array}{l}1 \text { home run } \\
\text { exit }\end{array}$ & $\begin{array}{l}\text { Several } \\
\text { home runs } \\
\text { and failed } \\
\text { exits }\end{array}$ & $\begin{array}{l}1 \text { home run } \\
\text { exit }\end{array}$ & $\begin{array}{l}\text { Several } \\
\text { home run } \\
\text { exits }\end{array}$ \\
\hline $\begin{array}{l}\text { Ventures as a } \\
\text { BA }\end{array}$ & 5 ventures & 6 ventures & 6 ventures & 8 ventures \\
\hline Exits as a BA & 0 exits & 3 exits & 3 exits & 5 exits \\
\hline
\end{tabular}


All four business angels have prior experience as entrepreneurs themselves. As entrepreneurs, they were involved in manufacturing, marketing/franchising and consulting, active in industries including sports, IT, retail products, grocery, life science, and real estate. In Table 2, rows 1 and 2 summarize the previous entrepreneurial experience of each business angel and the kind of entrepreneurial exit generated by each business. Rows 3 and 4 provide data on each business angel describing his/her experience as an investor. They all have prior experience of investing in ventures, and have all made exits from earlier investments, foremost through trade sales, or in some cases, through an undesirable management buyout a last resort for the business angel (for an overview of venture capital exits, see Cumming and MacIntosh 2003).

In Table 3, the four ventures are described in rows 1 and 2 . They have all existed nearly ten years, and the time since investment in each case ranges between 3 to 9 years. In row 3 , the industry where each venture is active is described.

Table 3. Description of each venture.

\begin{tabular}{lllll}
\hline & Venture 1 & Venture 2 & Venture 3 & Venture 4 \\
$\begin{array}{l}\text { Age of venture } \\
\text { Time since }\end{array}$ & 10 years & 11 years & 11 years & 10 years \\
investment & 9 years & 9 years & 3 years \\
Industry & $\begin{array}{l}\text { University } \\
\text { spinoff }\end{array}$ & Manufacturing & IT & $\begin{array}{l}\text { University } \\
\text { Consultancy }\end{array}$ \\
\hline
\end{tabular}

In terms of their current business angel activities, the four cases reported in the current study, the common background in all four cases is that a period of time has passed since the business angel first invested in the venture. During this time, the ventures have performed according to expectations. In all four cases, the business angel involved perceived that there was a previous harmonic time of cooperation in developing the venture, where the venture and the investors all worked toward a common goal. However, towards the end of this time period, the ventures have not met expectations. 


\section{The background phase}

Thus, the four cases have as a common feature that there has been a time of cooperation that has come to a close. However, there are differences between the cases in terms of how each business angel was involved during the times of harmony. In Table 4, the roles of the business angels are described.

Table 4. Role of the business angels in each venture before negotiations.

\begin{tabular}{lllll}
\hline \multirow{2}{*}{ Role of BA } & Venture 1 & Venture 2 & Venture 3 & Venture 4 \\
& Large & Large & Minor & Large \\
minority & minority & shareholder & minority \\
& shareholder & shareholder & Chairman of & shareholder \\
& Lead investor & Lead investor & the board & Board \\
& Board & Board & & member \\
member & member & & \\
Number of BA & Several BA & Several BA & Sole BA & Several BA \\
Type of & Reciprocal & Reciprocal & Reciprocal & Negotiated \\
exchange & exchange (co- & exchange (co- & exchange & exchange \\
& entrepreneur) & entrepreneur) & (mentor to & (investor) \\
& & & CEO) & \\
\hline
\end{tabular}

In cases 1, 2, and 3, the business angel is one of the largest shareholders, besides the venture founder who is the majority owner. In cases 1 and 2, the business angels are also lead investors, handling contacts with the venture for the other investors. As can be seen in row 2, in cases 1,2 and 4, there are several business angels who have invested. While the titles board member and chairman of the board, respectively, simply describes the formal position on the board of directors given to the business angel, the final row in Table 3 describes the type of social exchange that existed between the business angel and the venture before negotiations commenced. In three of the cases, the business angels were involved in solving problems, and had gradually earned the trust of the venture. They are described as co-entrepreneurs or mentors. Co-entrepreneurs are business angels who describe their working relationship with the venture as very active and informal, where they have gradually become part of the entrepreneurial team and are included in a trustful way as one 
among equals. Mentorship, on the other hand, denotes a situation where the business angel describes the relationship with the venture as trusting, but where the business angel holds a more senior position toward the rest of the venture members. In these three cases, there is an ongoing, reciprocal, trusting exchange, between the business angel and the venture.

In the fourth venture, the business angel has not worked in close cooperation with the venture, but rather has retained a distant investor role. In this case, where the business angel had not developed any informal relationship, there is a negotiated exchange between the business angel and the venture, taking place during discrete, formal episodes of contact and transaction, as evidenced in board meetings and similar.

\section{Perceptions and expectations on negotiations}

The background phase also encompasses perceptions and expectations, such as how the actors conceptualize and define the reasons for negotiation. In case 1, the venture had repeatedly fallen behind in meeting milestones, and funding had run out. Given that the venture had underperformed over and over again, the investors proposed that new funding be supplied at a lower valuation if certain future milestones were not reached. However smart this solution seemed, the venture founder-CEO opposed this proposal vehemently, arguing that the venture's inability to meet milestones was merely a temporary setback and did not reflect the value of the venture. It seemed that for the founder, the question of valuation was not neutral, but equivalent to a price tag on his ability as an entrepreneur.

In case 2, the willingness to provide new funding no longer existed. There was strife among the founders and the venture team was not able to function properly. Despite promises made over and over again, changes had not been implemented. The investors felt that there was no potential in the venture and wanted to recover as much of their money as possible. The venture founder felt that the company was worth saving and had assembled a team to attempt a management buyout. The negotiation in this second case was over the financial terms for this MBO.

In the third case, the venture had suffered from poor performance in cycles recurring every year. Both sales and development goals had lagged, and there was a need to make venture members renew their efforts in order to survive in the long run. 
The problem arose in part because the venture members needed to manage both sales and production. Thus, when they focused on sales, performance grew, but in order to deliver on those deals, they needed to stop focusing on sales and start delivering value to customers. All in all, however, the venture members had grown accustomed to this cycle, and did not really feel the need to renew their efforts because current work conditions were comfortable in the short run, and were sufficient to support a comfortable life style.

In the fourth and final case, the venture had also suffered from bad performance over many years. Sales and developmental goals were missed repeatedly over the years, and work was inefficient. However, it was deemed that the venture still had technological promise, and the investors agreed on trying to help make the work carried out in the venture more efficient, through a change of work procedures.

As can be seen, in all four cases, the perceived need for negotiation is triggered by a lack of venture performance. It is interesting to note that, to the exception of many ventures, all four ventures have customers, although this varies from having a few early $R \& D$ projects to a customer base of more than a hundred regular clients. The end result in all four cases is a situation that leads the business angel in each case to a negotiation of either the terms of investment or of the work procedures.

\section{Intentions for choosing a good cop, bad cop strategy}

In the interviews, much of the time was devoted to discussing how the business angels perceived the situation, as well as their intentions for choosing the good cop, bad cop negotiation strategy. In cases 1,3 , and 4, the intention of the business angels was to rescue the relationship, while in case 2 , the business angel had resigned to withdrawing from the investment through helping the management in an MBO. Even so, the need to negotiate the terms of the MBO made the business angel choose a good cop, bad cop strategy.

In cases 1-3, a bad cop is introduced as part of the negotiation strategy. As noted earlier, case 4 differs from the other three in that this is the only case where the business angel has remained distant from the venture, in a negotiated exchange. Thus, the strategy in case 4 was to try to introduce a good cop, someone whose role it would be to develop a closer relationship to the venture. In all cases the investors try 
to balance between the obvious need to affect the venture forcefully, and the need to not increase the goal divergence between them.

Table 5. Emotions and intentions of the business angel in each case.

Case 1 "I have to remain in the relationship and cannot afford to become enemies with the entrepreneur."

"I want to make the venture team understand that there is a problem, but avoid direct confrontation."

Case 2 "This investment has reached its maximum potential, and we should leave it."

"We could make use of the relationships we had with venture members other than the CEO to gather information and create as good an end as the situation could offer."

Case 3 "The venture team is too lazy. I need to stir things up a little and get them working again."

"I don't want them to trust me blindly and ask me about everything. They have to make their own decisions and take responsibility for them."

Case 4 "I am pushing all I can as an investor but it is not enough. I need to bring someone else into the relationship who can get closer to the entrepreneur."

"I want the CEO to start delivering. I will give support in the form of one of the other investors who will work closely and build trust."

As can be seen from the quotations in Table 5, the intentions of the business angel include sending a message while avoiding direct confrontation. Furthermore, in case 2 it is stated that the intention is to utilize all relationships that the business angel has access to and activate them against the venture, in order to achieve the investors' long-term goals. In the third case, the intentions are not primarily to achieve the investors' long-term goals, but to force the venture to reconsider their actions and options and to take full responsibility for both good and bad performance. In the business angel's experience, this would invariably lead to a situation where the venture finally accepted the gravity of the situation, as represented in the objective figures in the performance sheets, and took responsibility through measures to work harder. In the fourth case, the business angel badly wanted the venture to start 
meeting milestones and perform better and had the intention of wanting to help the CEO in daily work.

\section{The negotiation process and outcome}

In this part, an in-depth description of the negotiation process in all four cases is provided, with quotations from the business angels, finished with a very short description of the outcome in each case.

In case 1 , the business angel handled all communication. The business angel had very good knowledge of what was going on inside the venture thanks to a close relationship with the $\mathrm{CEO}$, and could report to the other investors when things were starting to turn bad. This included actually suggesting some of the solutions. When the other investors ratified these suggestions for solutions, they could be taken back to the CEO, and presented as coming from the investors. The business angel told the CEO that the other investors were growing impatient and were threatening to withdraw from the venture. However, the business angel explained, if they cooperated, the venture could still be saved, if the CEO only would agree to the terms of the new funding. The alternative for the CEO was to choose between killing his entrepreneurial dream by refusing the investors, or to cooperate with the business angel, who was a trusted member of the venture team, and accept slightly worse terms for renewed financing. As explained by the business angel, in light of the lack of previous performance, the new terms were actually not unfavorable for the venture, as long as they met milestones. The CEO eventually agreed to the new terms of funding, and the business angel - good cop was able to remain in the entrepreneurial team all through and after the negotiation, untainted by the pressure applied to the CEO by the other investors.

In case 2, the business angel handled the planning of the MBO in close cooperation with the venture, over a time period of several months. However, when the time drew near for the actual transaction, a fellow investor took over and negotiated the specific final details of the MBO. In the mind of the business angel, they had become too much like friends over the time period when the plans had been laid out, and the business angel was unable to switch to toughness during the coming negotiations with any credibility. By remaining involved in the final negotiation, the outcome would have been far worse. Bringing another investor in, as a bad cop 
focusing only on the details without any emotional ties, led to a better deal; not only for the investors, but also for the venture. The final deal ended up including some initial funding by the investors in order to get the MBO up and running. The business angel involved in case 2 suggested that the venture would have been unable to suggest such a solution to anyone besides a bad cop.

In case 3 , the business angel made a tradition of inviting the venture accountant to formal meetings from time to time. The business angel and the accountant would show up together, and then the meeting would begin. Following a formal meeting agenda closely, the business angel would eventually come to the point where current financial status was to be discussed. The accountant would then be invited to speak in order to present the almost always dismal financial report, and would finish the presentation with some normative statements as to the extreme gravity of the figures and that the money would run out in six months if nothing was done immediately. The accountant would then step aside and not speak again. Taking up the discussion after this bitter medicine, now that the venture team had taken the message of the accountant to heart, the business angel could focus entirely on constructive ways forward, out of the mess. This strategy had the effect that the business angel was never attributed as being the messenger of the poor performance and could stay part of the entrepreneurial team, whereas the accountant was in fact so associated with the delivery of bad tidings that the venture team almost felt fear. The accountant was completely associated with uncomfortable news of bad performance. Each year, at the annual meeting, after the same performance, the venture would change work procedures and increase performance for a few months, before falling behind again.

In case 4, the business angel invited a co-investor to begin working on operative matters with the venture, in the hope that this co-investor would become trusted by the CEO and would be able to identify and suggest ways of working more efficiently. If the co-investor was able to gain the confidence of the CEO, such suggestions could eventually result in changes in work procedures, thereby improving performance. While the co-investor worked alongside the CEO, in the hope of becoming a good cop, the business angel continued to act as a distant, formal investor. By the introduction of the good cop, the business angel hoped that there would be a contrast effect between them, whereby more pressure could be put on the 
CEO to change work procedures. If the good cop had been able to become accepted by the venture, as an established insider, that pressure could be channeled into work. In spite of much operative work over nearly a year's time, the co-investor was never able to become a trusted member of the entrepreneurial team, and was unable to become a good cop. Without a good cop, any pressure from the business angel merely served to make the CEO even more stubborn and defensive. In the end, the venture did not change work procedures.

\section{Analysis}

In reference to the classification suggested by Rafaeli and Sutton (1991), we see that in cases 2, 3 and 4, the good cop and bad cop are played by different people, in sequence (variation 1). This is the same variation that was studied by Hilty and Carnevale (1993) and Brodt and Tuchinsky (2000).

Table 6. The good cop, bad cop strategy in each case.

\begin{tabular}{|c|c|c|c|}
\hline & $\begin{array}{l}\text { Prior role of } \\
\text { business angel }\end{array}$ & $\begin{array}{l}\text { Good cop, } \\
\text { bad cop }\end{array}$ & Outcome \\
\hline Case 1 & $\begin{array}{l}\text { Insider co- } \\
\text { entrepreneur }\end{array}$ & $\begin{array}{l}\text { Introduced } \\
\text { a } \\
\text { hypothetical } \\
\text { bad cop - } \\
\text { attribution } \\
\text { to the other } \\
\text { investors }\end{array}$ & $\begin{array}{l}\text { Bad cop departs, trust preserved } \\
\text { between good cop and venture in } \\
\text { continued relationship }\end{array}$ \\
\hline Case 2 & $\begin{array}{l}\text { Insider co- } \\
\text { entrepreneur }\end{array}$ & $\begin{array}{l}\text { Introduced } \\
\text { a bad cop - } \\
\text { a co- } \\
\text { investor }\end{array}$ & Bad cop departs, MBO exit \\
\hline Case 3 & $\begin{array}{l}\text { Insider co- } \\
\text { entrepreneur }\end{array}$ & $\begin{array}{l}\text { Introduced } \\
\text { a bad cop - } \\
\text { the } \\
\text { accountant }\end{array}$ & $\begin{array}{l}\text { Bad cop departs, trust preserved } \\
\text { between good cop and venture }\end{array}$ \\
\hline Case 4 & Outsider investor & $\begin{array}{l}\text { Tried to } \\
\text { introduce a } \\
\text { good cop- } \\
\text { one of the } \\
\text { co-investors }\end{array}$ & Good cop has no effect on venture \\
\hline
\end{tabular}


In case 1, the bad cop is a hypothetical bad cop (variation 4 in Rafaeli and Sutton 1991). The message from this bad cop is thus only communicated by the good cop, but also in a sequence.

The main idea behind the good cop, bad cop strategy in ongoing relationships is nicely captured by the business angel in case 1 .

Sometimes I use the other investors as the bad guys and act more as a messenger than an owner myself...It is a question of avoiding any unnecessary drama. As owners, we must maintain a unified front, but it is simply easier to discuss a proposal if it comes from the investor group instead of from me. I need to be able to sit on the company board of directors in the future also, and cooperate with the venture team.

Three principal points can be made: that there is a need to accommodate both reciprocal and negotiated exchange, the definition of the strategy process and its sequence in the present findings, and finally, the way that the strategy enables attribution of negativity beyond the dyad.

\section{The need to accommodate both reciprocal and negotiated exchange}

Empirically, in these four cases we see evidence that business angels feel that they cannot adopt a position of negotiation vis-à-vis the venture once they have established a trusted position. In the negotiation model by Spector (1977), expectations and perceptions influence the way negotiations are carried out. Thus, choosing the good cop, bad cop negotiation strategy would imply that business angels expect negative reactions from the venture in case they should choose to bargain in person. In order to accommodate the need to negotiate, insider business angels introduce bad cops and become good cops themselves. Social exchange theory explained this in terms of two incompatible forms of exchange; reciprocal and negotiated, where reciprocal exchange produced higher levels of trust. The question posed was how these two forms of exchange were to be accommodated in cases where reciprocal exchange had been established and a need appeared to negotiate. The answer from these four cases is that the two forms of exchange are indeed 
perceived as incompatible, and as a consequence they are separated in different roles, the good cop and the bad cop. The two forms of exchange coexist, but the cases suggest that they cannot be accessed by the same business angel. This suggests that trust in the venture post-investment relationship is personal, just as argued by Ring and Van de Ven (1994).

\section{Defining the strategy and the sequence}

In earlier studies of good cop, bad cop negotiations, the question of sequence has proven of central importance. To reiterate, the effect has been strongest when the bad cop is introduced before the good cop (Hilty and Carnevale 1993; Brodt and Tuchinsky 2000). In ongoing relationships, events and sequences are always tricky to define (Langley 1999). However, drawing on the four cases, the following sequence of the good cop, bad cop negotiation strategy in ongoing relationships is proposed. The first step is when an investor who is an insider brings in a bad cop, and becomes a good cop at the same time. Thus, the first communication is by the bad cop, either in person or as a hypothetical bad cop communicating via the good cop. The second step is a communication with the good cop.

The sequence is defined as bad cop, good cop, which is similar to earlier results. In the three first cases, there are business angel insiders who become good cops by introducing bad cops, and negotiation ensues. However, in the fourth case, there is no reciprocal exchange when negotiations commence. Instead, there is a business angel outsider, who tries to introduce a good cop, but fails. The fourth case suggests that, in ongoing relationships, it takes time to become a good cop of any use during negotiations. In the fourth case, the relationship stays essentially negotiated. In the three other cases, where there was a reciprocal exchange between the business angel and the venture previous to negotiations, the business angel became a good cop during negotiations and then continued to have a reciprocal exchange after negotiations were terminated. The four cases suggest that although the good cop, bad cop strategy may be powerful in its emotional contrast effect (cf. Brodt and Tuchinsky 2000), in ongoing relationships, there must be someone who is a venture insider who is willing to play the good cop in order for the strategy to work. 


\section{Attribution of negativity to the bad cop}

A key to understanding the function of the good cop, bad cop strategy in ongoing relationships seems to lie in the preservation of the reciprocal exchange, by sheltering the trusted business angel from negotiated exchange, primarily by attributing the negotiated exchange to someone else. There is a need to negotiate, but for the business angel who has reached the dimension of reciprocal exchange, access to the form of exchange necessary for distributive bargaining is possible only indirectly, through someone else or through attribution to someone or something else.

In all three cases where the business angel has established a reciprocal exchange, there is attribution of negativity to the bad cop. In our four cases, examples of the bad cops include syndication partners, and legal-financial experts, enabling the good cop to remain trusted.

In this sense, the bad cop is used for scapegoating (Bonazzi 1983; Chelliah and Davis 2010). The bad cop takes the blame, and assumes the negativity associated with the pressure and toughness of the bad cop negotiation. If the tactics used during negotiations are perceived as unfair by one side, that party may still harbor hostility towards the other party, even after the dispute has been settled (cf. Kaufmann and Stern 1988). In our cases, any such retained hostility is directed toward the scapegoat bad cop. However, as cautioned by Bonazzi (1983), the paradox of a scapegoat is that it is apparent to most that the scapegoat is not really the only responsible for the action, but the blame is credible enough. Providing a causal account is associated with greater feelings of interactional fairness (Bies and Moag, 1986), to the extent that it is perceived as adequate (Bies and Shapiro 1987). Thus, in line with interactional justice, causal attribution to a bad cop needs to be relevant and credible in order to have any effect towards the venture.

In the cases, we see justification by attribution to an actor or a hypothetical actor whose exchange is negotiated. Here, the present study could also link to procedural justice in general, by arguing that the reciprocal form has certain legitimate procedures and the negotiated form others. Hence, a word of caution may be in order, as the limits of this strategy are considered. In some situations, if the roleplaying involved in scapegoating gets too obvious, perhaps the reciprocal exchange is tainted by the negotiated exchange. In such instances, bringing in a bad cop could corrupt the existing relationship. 


\section{Conclusions}

The present paper contributes to the research on post-investment involvement of business angels by analyzing negotiation strategies through social exchange theory, presenting new empirical data and contributing to theory. The present study suggests that the involvement of business angels in their ventures should be conceptualized in terms of different roles, and that the good cop, bad cop strategy is a way of managing conflict between these roles.

Specifically, an investor who has established an insider role, such as a coentrepreneur or a mentor, based on reciprocal exchange, will try to avoid reverting to the negotiated investor role. This suggests that - right or wrong - investors believe that such a role transition would be problematic, and that even if negotiations were successful, the trustful relationship would have been changed into a relationship with less trust. Instead, the negotiation needs to be carried out by someone else, hence the introduction of the bad cop. An important function of the good cop, bad cop strategy is to allow for scapegoating, as the bad cop is attributed with the negativity associated with negotiations. Furthermore, the emotional contrast effect creates a situation where both the bad cop and the good cop can cooperate: the bad cop exerts pressure and the good cop is able to channel it into constructive action. Because the bad cop is used as the source of all negative communication, the good cop can stay out of the negotiation, and focus on constructive solutions to how the negotiations can be brought to a close.

The contribution to the negotiation literature is in the empirical focus of this study on ongoing relationships. Criminal interrogation, bill collecting, and experiments share the feature of dealing with single transactions, rather than relationships. In the present study, the focus is on the good cop, bad cop strategy as it is enacted in long-term relationships. To the extent that the parties are to stay in the relationship after the negotiation, this means that the strategy needs to be played out in a way such that the retained hostility is minimized in the future relationship. In the earlier studies, the good cops had to rely on their ability to impress the adversary by dramatic effect during a single transaction, whereas in the present study, the good cop, and to some extent even the bad cop, are well-known from long time-periods of previous interaction in the relationship. To the extent that good cop and bad cop behavior is congruent with earlier behavior, this might increase the credibility of the 
strategy, and conversely, acting completely out of character would presumably not be very convincing.

Yet another perspective on the good cop, bad cop strategy may be in terms of how perceived relative power influence negotiations. It has been shown that smaller power difference will lead to agreements of greater integrativeness: when parties perceive that they are of equal power, their negotiations will be more oriented towards cooperative solutions (Wolfe and McGinn 2005). It has been argued that an investor holds more power than the venture (cf. Saam 2007). In the present setting, one could conceive of the business angel insider as being perceived as someone of more equal power than a business angel outsider, who would presumably be regarded as a more stereotypical owner. In order to increase the likelihood of reaching satisfactory agreements in negotiations, the insider business angel would want to stick to that role as long as possible. Continuing in this vein, one may speculate whether the introduction of the bad cop, with a greater power distance, is in fact a way of using the emotional contrast effect (Rafaeli and Sutton 1991) to create a perception of the good cop as even more equal to the venture in terms of relative power. Such a perception of similarity may facilitate negotiations.

One area of future research includes understanding why certain negotiations are managed within the ordinary dyadic relationship, whereas others are instead dealt with through the good cop, bad cop strategy. Are there certain negotiations that are within the legitimate bounds of the action accessible to the insider, where there is no need for a bad cop? Another area is to understand how common the strategy is within ongoing relationships, starting with business angels and other investors. However, it may not stop with investor relationships. The fact that the good cop, bad cop negotiation strategy seems to be such a powerful way of preserving trust in ongoing relationships, suggests that it could be a useful governance strategy in general, not only during negotiations and not only in investment relationships. 


\section{References}

Amatucci, F. M., and J. E. Sohl, 2004. Women Entrepreneurs Securing Business Angel Financing: Tales from the Field. Venture Capital 6: 181-196.

Arthurs J. D., and L. W. Busenitz. 2003. The Boundaries and Limitations of Agency Theory and Stewardship Theory in the Venture Capitalist/Entrepreneur Relationship. Entrepreneurship Theory and Practice 28: 145-162.

Bies, R. J., and J. F. Moag. 1986. Interactional Justice: Communication Criteria of Fairness. In Research on Negotiations in Organizations 1, ed. R.J. Lewicki, B. H. Sheppard, and M. H. Bazerman, 43-55. Greenwich, CT: JAI Press.

Bies, R. J., and D. L. Shapiro. 1987. Interactional Fairness Judgments: The Influence of Causal Accounts. Social Justice Research 1: 199-218.

Bonazzi, G. 1983. Scapegoating in Complex Organizations: The Results of a Comparative Study of Symbolic Blame-Giving in Italian and French Public Administration. Organization Studies 4: 1-18.

Brettel, M. 2003. Business Angels in Germany: A Research Note. Venture Capital 5: 251-268.

Brodt, S., and L. Thompson. 2001. Negotiating teams: A levels of analysis approach. Group Dynamics: Theory, Research, and Practice 5, 208-219.

Brodt, S. E., and M. Tuchinsky. 2000. Working Together but in Opposition: An Examination of the "Good-Cop/Bad-Cop" Negotiating Team Tactic. Organizational Behavior and Human Decision Processes 81: 155-177.

Bruce, C. 2007. Questions Arising about Emergence, Data Collection, and Its Interaction with Analysis in a Grounded Theory Study. International Journal of Qualitative Methods 6: 51-68.

Chelliah, J., and D. Davis. 2010. But do you like your (expensive management) consultant?. Journal of Business Strategy 31: 34-42.

Christensen, E., Wuebker, R., and R. Wüstenhagen. 2009. Of Acting Principals and Principal Agents: Goal Incongruence in the Venture Capitalist-Entrepreneur Relationship. International Journal of Entrepreneurship and Small Business 7: 367-388.

Collewaert, V. 2012. Angel Investors' and Entrepreneurs' Intentions to Exit Their Ventures: A Conflict Perspective. Entrepreneurship Theory and Practice 36: 753-779. 
Collewaert, V., and Y. Fassin. 2013. Conflicts Between Entrepreneurs and Investors: the Impact of Perceived Unethical Behavior. Small Business Economics 40: 635-649.

Costa, A. C., and K. Bijlsma-Frankema. 2007. Trust and Control Interrelations New Perspectives on the Trust-Control Nexus. Group \& Organization Management 32: 392-406.

Cumming, D. J., and J. G. MacIntosh. 2003. Venture Capital Exits in Canada and the United States. University of Toronto Law Journal 53: 101-200.

Das, T. K. and B-S. Teng. 1996. Risk Types and Inter-Firm Alliance Structures. Journal of Management Studies 33: 827-843.

Das, T. K. and B-S. Teng. 2001. Trust, Control, and Risk in Strategic Alliances: An Integrated Framework. Organization Studies 22: 251-283.

Davis, J., Schoorman, H., F. D. and L. Donaldson. 1997. Toward a stewardship theory of management. Academy of Management review 22: 20-47.

De Dreu, C. K., and L. R. Weingart. 2003. Task versus relationship conflict, team performance, and team member satisfaction: a meta-analysis. Journal of applied Psychology 88: 741-749.

Deci, E. L., Koestner, R., and R. M. Ryan. 1999. A Meta-Analytic Review of Experiments Examining the Effects of Extrinsic Rewards on Intrinsic Motivation. Psychological Bulletin 125: 627-668.

Eisenhardt, K. M. 1989. Building Theories from Case Study Research. Academy of Management Review 14: 532-550.

Falk, A., and M. Kosfeld. 2006. The Hidden Costs of Control. The American Economic Review, 96: 1611-1630.

Fiet, J. O. 1995. Risk-Avoidance Strategies in Venture Capital Markets. Journal of Management Studies 32: 551-574.

Glaser, B. G. and A. L. Strauss. 1967. The Discovery of Grounded Theory: Strategies for Qualitative Research. Chicago: Aldine.

Hilty, J. A., and P. J. Carnevale. 1993. Black-hat/white-hat strategy in bilateral negotiation. Organizational Behavior and Human Decision Processes 55: 444-469.

Jehn, K. A. 1995. A multimethod examination of the benefits and detriments of intragroup conflict. Administrative science quarterly 40: 256-282. 
Jensen, M. C. and W. H. Meckling. 1976. Theory of the Firm: Managerial Behavior, Agency Costs and Ownership Structure. Journal of Financial Economics 3: 305-360.

Kaufmann, P. J. and L. W. Stern. 1988. Relational Exchange Norms, Perceptions of Unfairness, and Retained Hostility in Commercial Litigation. Journal of Conflict Resolution 32: 534-552.

Langley, A. 1999. Strategies for Theorizing from Process Data. Academy of Management review 24: 691-710.

Lindsay, N. J. 2004. Do Business Angels Have an Entrepreneurial Orientation?. Venture Capital 6: 197-210.

Lindström, G., and C. Olofsson. 2001. Early Stage Financing of NTBF:s: An Analysis of Contributions from Support Actors. Venture Capital 3: 151-168.

Lockett, A., D. Ucbasaran, and J. Butler. 2006. Opening Up the Investor-Investee Dyad: Syndicates, Teams, and Networks. Entrepreneurship Theory and Practice 30: 117-130.

Macht, S. A. 2011. Inexpert Business Angels: How Even Investors With 'Nothing to Add' Can Add Value. Strategic Change 20: 269-278.

Madill, J. J., G. H. Haines, Jr, and A. L. Riding. 2005. The Role of Angels in Technology SMEs: A Link to Venture Capital. Venture Capital 7: 107-129.

Mason, C. M., and R. T. Harrison. 2002. Is It Worth It? The Rates of Return from Informal Venture Capital Investments. Journal of Business Venturing 17: 211236.

Mason, C. M., and R. T. Harrison. 2008. Measuring Business Angel Investment Activity in the United Kingdom: a Review of Potential Data Sources. Venture Capital 10: 309-330.

Miles, M. B. and A. M. Huberman. 1994. Qualitative Data Analysis. Newbury Park, CA: Sage.

Molm, L. D. 2000. Theories of Social Exchange and Exchange Networks. In Handbook of Social Theory, ed. G. Ritzer, and B. Smart, 260-272. Thousand Oaks: Sage.

Molm, L. D. 2003. Theoretical Comparisons of Forms of Exchange. Sociological Theory 21: 1-17. 
Molm, L. D., G. Peterson, and N. Takahashi. 2003. In the Eye of the Beholder: Procedural Justice in Social Exchange. American Sociological Review 68: 128-152.

Parkhe, A. 1993a. Strategic Alliance Structuring: A Game Theoretic and Transaction Cost Examination of Interfirm Cooperation. Academy of Management Journal 36: 794-829.

Parkhe, A. 1993b. "Messy” Research, Methodological Predispositions, and Theory Development in International Joint Ventures. Academy of Management Review 18: 227-268.

Paul, S., G. Whittam, and J. Wyper. 2007. Towards a Model of the Business Angel Investment Process. Venture Capital 9: 107-125.

Podsakoff, P. M.; S. B. MacKenzie, J-Y. Lee, and N. P. Podsakoff. 2003. Common Method Biases in Behavioral Research: A Critical Review of the Literature and Recommended Remedies. Journal of Applied Psychology 88: 879-903.

Politis, D. 2008. Business Angels and Value Added: What Do We Know and Where Do We Go? Venture Capital 10: 127-147.

Politis, D., H. Landström. 2002. Informal Investors as Entrepreneurs - the Development of an Entrepreneurial Career. Venture Capital 4: 78-101.

Polkinghorne, D. E. 2005. Language and Meaning: Data Collection in Qualitative Research. Journal of Counseling Psychology 52: 137-145.

Puranam, P, and B. S. Vanneste. 2009. Trust and governance: Untangling a tangled web. Academy of Management Review 34: 11-31.

Rafaeli, A., and R. I. Sutton. 1991. Emotional contrast strategies as means of social influence: Lessons from criminal interrogators and bill collectors. Academy of Management Journal 34: 749-775.

Ring, P. S., and A. H. Van de Ven. 1994. Developmental Processes of Cooperative Interorganizational Relationships. Academy of Management Review 19: 90118.

Ross, S. A. 1973. The Economic Theory of Agency: The Principal's Problem. American Economic Review 63: 134-139.

Rousseau, D. M., S. B. Sitkin, R. S. Burt, and C. Camerer. 1998. Not So Different After All: A Cross-Discipline View of Trust. Academy of Management Review 23: 393-404. 
Saam, N. J. 2007. Asymmetry in information versus asymmetry in power: Implicit assumptions of agency theory?. The Journal of Socio-Economics 36, 825-840.

Sapienza, H. J. and M. A. Korsgaard. 1996. Procedural justice in entrepreneurinvestor relations. Academy of management Journal 39: 544-574.

Sapienza, H. J., and A. K. Gupta. 1994. Impact of Agency Risks and Task Uncertainty on Venture Capitalist-CEO Interaction. Academy of Management Journal 37: 1618-1632.

Schein, E. H. 2006. Organizational Culture and Leadership. 3rd. Ed. John Wiley \& Sons.

Shah, S. K., and K. G. Corley. 2006. Building Better Theory by Bridging the Quantitative-Qualitative Divide. Journal of Management Studies 43: 18211835 .

Shane, S. 2008. Fool's Gold?: The Truth Behind Angel Investing in America. Oxford University Press.

Shane, S., and D. M. Cable. 2002. Network Ties, Reputation, and the Financing of New Ventures. Management Science 48: 364-381.

Sohl, J. E. 1999. The Early-Stage Equity Market in the USA. Venture Capital 1: 101120.

Spector, B. I. 1977. Negotiation as a psychological process. Journal of Conflict Resolution 21: 607-618.

Stake, R. E. 2005. Qualitative Case Studies. In The Sage Handbook of Qualitative Research, 3rd Ed., ed. N. K. Denzin and Y. S. Lincoln, 443-466. Thousand Oaks: Sage.

Sudek, R. 2006. Angel investment criteria. Journal of Small Business Strategy 17: 89103.

Sörheim, R. 2005. Business Angels as Facilitators for Further Finance: An Exploratory Study. Journal of Small Business and Enterprise Development 12: $178-191$.

Tosi, H. L., Katz, J. P., and L. R. Gomez-Mejia. 1997. Disaggregating the agency contract: The effects of monitoring, incentive alignment, and term in office on agent decision making. Academy of Management Journal 40: 584-602. 
Van Osnabrugge, M. 2000. A comparison of business angel and venture capitalist investment procedures: an agency theory-based analysis. Venture Capital 2: 91-109.

Wolfe, R. J., and K. L. McGinn. 2005. Perceived relative power and its influence on negotiations. Group Decision and Negotiation, 14: 3-20.

Yin, R. K. 1994. Case Study Research, Design and Methods, 2nd ed. Newbury Park, CA: Sage.

Yitshaki, R. 2008. Venture capitalist-entrepreneur conflicts: An exploratory study of determinants and possible resolutions. International Journal of Conflict Management 19: 262-292. 